\title{
MEDIAÇÃO E APROPRIAÇÃO DA INFORMAÇÃO NAS CARTAS DE LEITORES: PRÁTICAS DE INFORMAÇÃO E LEITURA DO JORNAL BOM DIA BAURU $^{1}$
}

\author{
MEDIACIÓN Y APROPIACIÓN DE LA INFORMACIÓN EN \\ LAS CARTAS DE LECTORES: PRÁCTICA DE \\ INFORMACIÓN Y DE LECTURA DEL PERIÓDICO BOM DIA \\ BAURU
}

\begin{abstract}
Tamara de Souza Brandão Guaraldo - tamara@faac.unesp.br Doutora em Ciência da Informação pela Universidade Estadual Paulista

(UNESP/Marília). Professora dos cursos de Comunicação Social da

UNESP/Bauru.
\end{abstract}

\section{RESUMO}

Introdução: $O$ presente estudo trata sobre o sujeito leitor em sua prática de informação e leitura no jornal popular BOM DIA Bauru. Desse modo, o artigo se propôs estudar a questão do leitor e sua prática de informação e leitura cotidiana nas cartas de leitores.

Objetivo: Conhecer o sujeito leitor em sua prática de leitura de jornal, numa mediação em que efeitos de sentido são produzidos a partir da apropriação da informação.

Metodologia: Foram selecionadas trinta cartas de leitores tendo como tema a mudança de layout e editorias do jornal em setembro de 2010, com uso da metodologia da Análise de Discurso.

\footnotetext{
${ }^{1}$ Esse artigo é parte da tese defendida pela autora no Programa de Pós-Graduação em Ciência da Informação na Universidade Estadual Paulista - UNESP- Marília/SP. Banca examinadora: Prof. Dr. Oswaldo Francisco de Almeida Junior (Orientador), Prof. Dr. Carlos Cândido de Almeida, Prof. Dr. Carlos Alberto Ávila Araújo, Profa. Dra. Sonia de Brito, Profa. Dra. Henriette Ferreira Gomes.
} 
Resultados: As cartas de leitores analisadas demonstram que os leitores são ativos na maneira em que aceitam, negam ou reproduzem o discurso do jornal no processo de recepção. Os leitores do BOM DIA Bauru apontam como critérios de relevância da informação: o tamanho da fonte, o layout, a impressão, o uso e o conteúdo.

Conclusões: Destaca as apropriações e resistências do público leitor em sua prática de informação e leitura e contribui para ampliar as discussões sobre a variedade de leitores existentes, numa realidade de mudança socioeconômica que suscita contradições, mas que permite a esse leitor adquirir materiais para ler.

Palavras-chaves: Práticas de informação. Mediação. Cartas de leitores. Recepção.

\section{INTRODUÇÃO}

Esse artigo apresenta uma pesquisa sobre práticas de informação e leitura referente às cartas de leitores do jornal BOM DIA Bauru. Este jornal foi escolhido, pois foi lançado em 2005 no interior paulista, época de aumento da leitura de jornais no país, e em setembro de 2010 realizou uma mudança em seu layout e conteúdo. O objetivo principal da pesquisa foi conhecer o sujeito leitor em sua prática de leitura de um jornal popular, numa mediação em que efeitos de sentido são produzidos a partir da apropriação da informação.

Para Capurro (2003), a informação, não toma como referência um sujeito ou usuário isolado, mas determinada comunidade e um campo específico de conhecimento ou de ação na qual o usuário (ou leitor) está implícita ou explicitamente inserido. Por isso, foram selecionadas 30 cartas de leitores tendo como tema o reposicionamento do jornal com mudanças de layout e editorias em setembro de 2010. Para alcançar os objetivos propostos, utilizamos como metodologia a Análise de Discurso.

Abordar o leitor do jornal popular, e de modo particular, do BOM DIA Bauru, permite-nos entender a mediação leitor e jornal que se dá nas práticas de informação, e o papel que o leitor ocupa no jornal. O nosso ponto de partida, porém, não é o jornal como documento, mas as práticas de informação e leitura de seu público leitor, e envolve o questionamento que a ele faremos. O problema de pesquisa apresentou algumas considerações dialéticas: a atividade do leitor, a recepção que o leitor fazia do jornal e como se apropriava da informação em sua 
prática de leitura, o que era relevante para ele, além de quais posições poderia ocupar para ser o sujeito leitor do referido jornal.

Nesse trabalho interessa-nos destacar as práticas de informação relacionadas à mediação e apropriação, que envolvem ações de informação na cotidianidade. As práticas de informação compreendem as ações com a informação, como o registro, o armazenamento, a recuperação, a gestão, o acesso, o uso, a busca, a circulação, o hábito, o aprendizado, a mediação, a socialização, a leitura, e dependem das circunstâncias nas quais o ser humano encontra-se situado, é onde se põe em ação o conhecimento. A ação de informação se constitui como "[...] informação para algo e para alguém" (GONZÁLEZ DE GOMEZ, 2004, p. 62).

Nas práticas de informação se inserem os meios de informação e as ações relacionadas a eles, juntamente com os sujeitos envolvidos, a circulação social dos meios, o trabalho com esses meios e os textos. As práticas de informação são, portanto, sempre relacionais e segmentadas, pois referentes a determinados grupos sociais e contextos específicos, que mobilizam efeitos de sentido de acordo com o local, a ideologia e a cultura de seus participantes (GUARALDO, 2013).

Como prática de informação, a leitura de jornal permanece resiliente, pois este impresso é um meio de informação que tem como uma de suas características a universalidade, sendo feito para todo leitor que se encontra em sua abrangência geográfica e seja capaz de lê-lo. E o papel do jornal é o de informar e situar o leitor na vida cotidiana, social e política, ampliando seu conhecimento. Embora se admita que o jornal impresso, tal como o conhecemos hoje, sofre forte concorrência dos meios eletrônicos, tendo, inclusive a sua morte constantemente anunciada, ele ainda é um forte meio de informação. No intervalo de 2003 a 2007, segundo a pesquisa "Tendências Mundiais da Imprensa"2, o Brasil registrou um aumento de 24,93\% na circulação de jornais. Nesse período, o destaque no Estado de São Paulo, foi a Rede Bom Dia de Comunicações, que edita jornais e mantêm um portal online do conteúdo do jornal.

Acredita-se que a análise se justifica pela relevância que apresenta, por focalizar um jornal que nasceu num período - a primeira década do Século XXI - de intensas transformações econômicas e sociais no país, que criaram condições para 
esse aumento na leitura, com a ascensão social de camadas da população de menor renda refletida pela mobilidade social com cerca de 40 milhões de pessoas que entraram para a classe média no país, que subiu de 65,9 milhões para 105,5 milhões de brasileiros, um crescimento de praticamente 60\% (TABAK, 2012). Esse é o público alvo do jornal, que aparece na página "Sua Opinião", na seção de cartas de leitores intitulada A voz e a vez do leitor, situada na página 07 do referido jornal. Investigar a relação entre o jornal e o leitor pela prática de informação, situa a pesquisa no campo da mediação, pois os textos foram analisados a partir da apropriação da informação e da posição que os participantes assumiram frente à prática de leitura e produziram o seu discurso.

\section{MEDIAÇÃO E APROPRIAÇÃO DA INFORMAÇÃO}

A mediação enfatiza o caráter social da informação, de que a mesma não existe fora da sociedade e da cultura, demonstrando as singularidades da questão informacional, das condições de produção e apropriação da informação. O conceito de mediação encontrou campo fértil em pesquisas que apontam que nada é imediato e, portanto, "[...] demonstram que o conhecimento e o significado nunca nos são simplesmente dados, mas precisam ser elaborados" (JEANNERET, 2009, p. 26). É uma determinação em mostrar que nada pode ser dado como certo ou transparente nos fatos da cultura, de papéis sociais e formas simbólicas. Estudos de mediação recusam uma abordagem imediata dos fatos e põem em jogo os diferentes atores, procedimentos e dispositivos envolvidos numa dimensão simbólica e prática da cultura.

Alguns usos da noção de mediação são apontados por Davallon (2007): o primeiro é o uso comum, que supõe um acordo entre partes que tem interesse distinto, e comporta a ideia de reconciliação. Contudo, ainda mais comum é a concepção da mediação como um tipo de prática ou ação, ou seja, a ideia de servir de intermediário: "[...] o papel de intermediário facilitando a comunicação é suposto favorecer a passagem a um estado melhor" (DAVALLON, 2007, p. 06). Esse entendimento está presente na Ciência da Informação $(\mathrm{Cl})$ e na Comunicação quando apresentam procedimentos de mediação nas organizações e na atividade profissional de cada área. 
Esta vertente se encontra nos estudos de mediação da informação, como uma prática e um processo que engloba as ações de interferência em relação à informação, que podem ser desde ações diretas e conscientes, até indiretas e inconscientes, individuais ou coletivas, singulares ou plurais, que propiciem a apropriação da informação ${ }^{3}$ (ALMEIDA JUNIOR, 2009).

Uma preocupação da área refere-se não somente à gestão e a organização da informação, mas de como as pessoas se apropriam dessa informação. A informação não está no objeto e nem no sujeito, mas na mediação que se estabelece entre eles: "[...] a mediação da informação é um processo históricosocial. O momento em que se concretiza não é um recorte de tempo estático e dissociado de seu entorno. Ao contrário; resulta da relação dos sujeitos com 0 mundo" (ALMEIDA JUNIOR, 2009, p. 93).

Como seres históricos, somos capazes de optar, decidir, avaliar, pois toda ação humana envolve uma finalidade, ingênua ou crítica, e agir sobre um objeto significa não apenas compreendê-lo, mas também analisar a percepção que dele se tinha ou se tem ao atuar sobre ele: "[...] o ato de conhecer envolve um movimento dialético que vai da ação à reflexão sobre ela e desta a uma nova ação" (FREIRE, 2011, p. 80).

Para Paulo Freire (2011) não há práxis autêntica fora da unidade dialética da ação-reflexão, pois a consciência não se transforma a não ser na práxis, e o conhecimento não se transfere, se cria através da ação sobre a realidade. $\mathrm{O}$ conhecer tem origem no agir. Conhecer é se apropriar, tomar posse, mas ir além, pois implica agir e modificar uma circunstância. A apropriação da informação é um sair de si e buscar o outro, mas de modo discursivo, pois não se apropria do objeto tal como é, e sim de um conceito elaborado pelo pensamento.

Se a informação se realiza na mediação, não importa o modo de sua veiculação, mas o fato de que a mesma seja apropriada pelas pessoas (ALMEIDA JUNIOR, 2007). Na mediação, portanto, aparecem conceitos importantes, como a apropriação, a recepção e a interferência. Assim, aquele que faz o uso da

\footnotetext{
${ }^{3}$ Almeida Junior (2008) propõe inclusive reconsiderar o objeto da área de Cl que passaria a ser a mediação da informação. Um dos motivos é que as atividades culturais perpetradas por agentes informacionais são, muitas vezes, desconsideradas como próprias à área, devido a sua efemeridade. Para um maior entendimento do conceito de mediação, ver Bortolin (2010) que em sua tese realizou amplo levantamento bibliográfico sobre o termo na área de Ciência da Informação e outros domínios.
} 
informação é o ator central do processo de apropriação, um coprodutor da informação, pois "[...] a autoria deixa de ser única e passa a ser repartida, distribuída entre todos os que farão uso da informação em potência" (ALMEIDA JUNIOR, 2009, p. 97).

Outro autor que aborda a apropriação é Thompson (2009), que ao se dedicar aos estudos de uso, definiu a recepção como o processo que engloba a apropriação, sendo uma atividade rotineira e prática e não passiva, mas um processo em que os indivíduos usam as formas simbólicas para suas próprias finalidades. Além de ser pensada como atividade de rotina, a recepção não pode ser confundida com a aquisição de um meio, pois nem sempre implica uma interpretação: "[...] um livro pode ser comprado e nunca lido", diz o autor, pois "[...] adquirir é simplesmente tomar posse de, como se adquire outros objetos de consumo: carros, roupas, etc." (THOMPSON, 2009, p. 44). É que o indivíduo deve prestar atenção (ler, olhar, escutar) e interpretar o conteúdo simbólico do meio que exige diferentes graus de atenção.

Ao interpretar as formas simbólicas, os indivíduos as incorporam à própria compreensão que têm de si mesmos, do mundo e dos outros, como um veículo de reflexão e conhecimento, conforme conceitua Thompson (2009, p. 45):

\footnotetext{
Usarei o termo apropriação para me referir a este extenso processo de conhecimento e de autoconhecimento. Apropriar-se de uma mensagem é apoderar-se de um conteúdo significativo e torná-lo próprio. É assimilar a mensagem e incorporá-la à própria vida - um processo que muitas vezes acontece sem muito esforço, e outras vezes requer deliberada aplicação. É adaptar a mensagem à nossa própria vida e aos contextos e circunstâncias em que a vivemos; contextos e circunstâncias que normalmente são bem diferentes daqueles em que a mensagem foi produzida.
}

Assim, a apropriação é um processo que tem como pano de fundo a vida cotidiana e as conjunturas que a envolvem, porque para ser apropriada, qualquer mensagem precisa ser primeiro recebida e compreendida.

Para o estudo da recepção, no âmbito dos Estudos Culturais, Hall (1980) propôs o modelo Codificação/Decodificação, e teorizava que era possível perceber o poder hegemônico dos meios de informação mediante o estudo de processos sociais e ideológicos e não da psicologia individual. Ao invés de pensar em como a 
informação deve ser transferida ao receptor para que ele reaja da maneira esperada, Hall (1980) propõe pensar as forças que entram em jogo na produção da mensagem, buscando a ideologia do discurso e como o emissor consegue convencer o receptor de que está representando o sentido comum, quando na realidade representa a cultura dominante. $O$ modelo alude que os receptores podem escolher entre três leituras na recepção: 1- dominante: estar de acordo com a mensagem, postura hegemônica-dominante; 2- negociada: escolher uma via intermediária, mescla de códigos adaptativos e de oposição; 3- oposição: estar em desacordo com a mensagem, o receptor pode entender perfeitamente a inflexão tanto conotativa como literal oferecida pela informação, mas decodifica a mensagem de um modo contrário. Porém, é preciso ter em conta a situação do receptor, o seu contexto e sua relevância cultural, pois isso geraria a variabilidade de interpretação, o que o antigo modelo de Shannon e Weaver não contemplava, pois havia sido concebido em função da transmissão ótima da informação, tratando a não compreensão da mesma devido ao "ruído". Hall pensa a comunicação e a informação a partir de um viés cultural, considerando as diferenças na interpretação da informação, a sua recepção e apropriação em relação ao sentido atribuído pelos emissores e pelos receptores.

Almeida Junior (2009) também questiona o conceito de transferência de informação por ser inadequado ao se pensar a apropriação, já que indica uma troca ou mudança de um lugar a outro. É porque a informação não é meramente transmitida, mas integrada ao conhecimento, pois o transforma. Daí que o autor utiliza o termo mediação da informação ao lidar com sua recepção, e não transferência.

A ação de apropriar, como parte da recepção, é tornar algo próprio para um uso ou fim, um tomar para si, e que implica atividade, ainda que inconsciente. Para Almeida Junior (2007, p. 36), a apropriação "[...] pressupõe uma alteração, uma transformação, uma modificação do conhecimento, sendo assim uma ação de produção e não meramente de consumo".

E a maneira de se apropriar da informação é pela leitura desses meios, ou seja, a informação está na mediação sujeito e objeto, ou melhor, sujeito a sujeito, pois os documentos não são neutros, já que alguém os fez. A informação "[...] só pode se realizar, se fazer presente, se concretizar, com base e fazendo uso da 
leitura. Sem ela todas as ações realizadas nos espaços informacionais são inúteis e desprovidas de sentido, pois a informação deixa de ser apropriada" (ALMEIDA JUNIOR, 2007, p. 34).

A informação, para ser apropriada, depende da leitura, dos leitores e suas práticas mediando à construção do conhecimento. E a mediação é um recurso de investigação em Ciência da Informação e Comunicação que possibilita analisar objetos informacionais que são ao mesmo tempo, dispositivos técnicos, sociais e significantes (DAVALLON, 2007).

Nessa perspectiva, a informação nunca é simplesmente transmitida, pois os meios de informação são parte de práticas de informação e leitura, que buscam tornar possível a comunicação na sociedade, sendo um espaço em que os significados são construídos ou transformados.

\section{METODOLOGIA}

A análise qualitativa de um documento começa com a ideia de processo, do contexto social, de como esse se dirige a um público em circunstâncias particulares, sendo a tarefa do analista uma "leitura" do texto em termo dos seus símbolos (MAY, 2004). E do ponto de vista da leitura como mediação, vem a ideia da figura social que confere existência a atores que certas abordagens negligenciam. Para Jeanneret (2009, p. 27), "[...] o livro dá existência ao leitor, a fotografia à testemunha, as plataformas colaborativas ao engenheiro social", mas e o seu contrário? Essa é uma questão dialética: o jornal dá existência ao leitor, e o leitor, ao ler o jornal, Ihe dá a vida pela prática de leitura em que se apropria da informação. No leitor, o jornal encontra um lugar no qual viver.

Ainda que seja importante relacionar a informação aos seus autores, essa é utilizada de um modo que depende da situação social do público, do significado atribuído na leitura. A noção de leitura acompanha todo o desenvolvimento da Análise de Discurso desde o início de seu projeto em 1969 (PÊCHEUX, 2010a), como uma opção à abordagem documental de textos, em que, a partir do estudo do discurso, promovia condições para uma determinada prática de leitura: uma nova maneira de "ler". 
Para além da leitura de grandes textos ${ }^{4}$, a Análise de Discurso (AD) se preocupa em "[...] se pôr na escuta das circulações cotidianas, tomadas no ordinário do sentido" (PÊCHEUX, 2008, p. 48). Maingueneau (2011) afirma que nas Ciências Humanas e Sociais há uma preferência por grandes textos, como os literários, científicos, religiosos e governamentais, mas a Análise de Discurso não divide os textos em prestigiosos ou não prestigiosos, pois estuda os textos que circulam em uma sociedade. Esses textos do dia a dia são muitas vezes, apenas folheados, pois são efêmeros e invasores, como os cartazes, jornais, panfletos e propagandas, e para Maingueneau (2002) ainda que tenham menor prestígio social e a eles lançamos um olhar distraído, sem a realização de uma leitura profunda, são os materiais que mais estão em contato com a vida cotidiana.

Segundo Maingueneau (2011) a leitura de jornal não constitui uma interação em sentido habitual, que implica regras, parceiros e compartilhamento, além de regulação frente aos outros, pois não há possibilidade de resposta imediata. Pêcheux (2010b) lembra que em certos discursos o destinador não recebe nenhum tipo de resposta do destinatário:

Trataremos aqui unicamente desse caso particular do discurso monólogo, que podemos identificar na condução do relato, do testemunho, da prece, da demonstração pelo exemplo, casos em que, no mínimo, o destinatário só se encontra presente na situação pela imagem que o destinador faz dele. (PÊCHEUX, 2010a, p. 91).

Dessa maneira, o texto não é um produto, mas um processo no qual o leitor não apreende um sentido que está lá, ele atribui sentidos ao texto, se apropria dele. A leitura é produzida e se procura determinar o processo e suas condições de produção. Quando o leitor se apropria do texto, encontra nele um outro, um leitor virtual já constituído pelo autor, e com ele precisa relacionar-se. O leitor ideal não existe, e sim um leitor moldado pela instituição em que se inserir, pois o leitor real tem uma história e um posicionamento frente a outras leituras (NUNES, 2003). Para

\footnotetext{
${ }^{4} \mathrm{O}$ termo texto e discurso não são intercambiáveis, pois o texto é a unidade que o analista tem diante de si e do qual realiza sua leitura remetendo-o a um discurso que ganha sentido em relação às condições de produção em uma conjuntura dada: "[...] um texto e só uma peça de linguagem de um processo discursivo bem mais abrangente e é assim que deve ser considerado. Ele é um exemplar do discurso" (ORLANDI, 2009, p. 72).
} 
a $A D$ é dessa relação que se instaura o processo de leitura: do jogo entre o leitor virtual e o leitor real, numa relação de efeitos de sentido de um sobre o outro.

Neste ponto de vista, a leitura é uma relação histórica e social, ainda que mediada por objetos. Orlandi (2008) critica aqueles que falam de interação leitor e texto no momento da leitura, porque o leitor não interage com o texto, numa relação sujeito e objeto, mas com outro sujeito, o leitor virtual e o próprio autor. O autor destina o seu texto para um leitor virtual, constituído no ato da escrita e esse "[...] tanto pode ser seu "cúmplice" quanto seu "adversário" (ORLANDI, 2008, p. 9).

Outra questão que a Análise de Discurso não considera em relação à leitura é sobre a existência de um autor onipotente, com intenções que controlam a significação do texto. Considera também que um texto nunca é transparente, e nega a existência de um leitor onisciente com uma capacidade de compreensão que domina os múltiplos sentidos do processo de leitura. Na leitura há o lugar do jogo de sentidos.

Com isso, visamos fornecer subsídios para que se considere a prática de leitura não como uma atividade neutra ou definitiva, mas como determinada pelas práticas sociais, e, portanto, relacionável ao espaço de representações possíveis nesse contexto. (NUNES, 2003, p. 44).

Quando lemos não consideramos apenas o que está dito na superfície discursiva, mas também o que está implícito, em profundidade, porque apesar de não estar dito, pode estar significando: sustentando o que é dito, o que está suposto para que se entenda o que está dito, aquilo à que se opõe e as nuances no dizer: "[...] Isso mostra como a leitura pode ser um processo bastante complexo e que envolve muito mais do que habilidades que se resolvem no imediatismo da ação de ler. Saber ler é saber o que o texto diz e o que ele não diz, mas o constitui significativamente" (ORLANDI, 2008, p. 11).

As condições de produção da leitura se dão na tensa relação entre paráfrase, ou seja, repetição, e polissemia, diferença e criatividade, que constituem qualquer discurso. A leitura parafrástica é caracterizada pela reprodução ou reconhecimento de um sentido que se supõe ser o do texto (do autor). Já a leitura polissêmica é aquela que se define pela atribuição de múltiplos sentidos ao texto. Na produção da leitura também entram outros aspectos importantes como a incompletude, que 
envolve o implícito e a intertextualidade. Tanto o reconhecimento quanto à atribuição de sentidos estão inseridos na produção da leitura.

\subsection{Jornal Bom Dia Bauru}

O jornal BOM DIA surgiu com o crescimento dos jornais no país, pois veio à luz em 2005, e se apresenta como um jornal regional. Porém, suas características o colocam na fronteira entre ser um jornal regional, cuja característica está na sua circulação e ênfase nos temas locais e nacionais que sejam de interesse de seu público leitor, e jornal popular, que privilegia temáticas como esportes, prestação de serviços, celebridades e pouco noticiário internacional. E sua característica de jornal regional é evidenciada pela sua circulação, que não se restringe a cidade de Bauru, mas também circula em Agudos, Areiópolis, Duartina, Pederneiras, Piratininga, São Manoel, Lençóis Paulista e Botucatu. Tem circulação média de cinco mil exemplares diários $^{5}$. O BOM DIA Bauru tem as seguintes características: é diário, pois circula de segunda a domingo, colorido (impresso em quatro cores), tem em média 32 páginas durante a semana e 88 aos domingos e é vendido por um real. $O$ formato do jornal é tabloide berlinense e publica notícias, editoriais, artigos opinativos, suplementos especiais e se apresenta em bloco único.

\subsection{A constituição do corpus e os objetivos da análise}

Antes da análise, é imprescindível localizar os textos em suas condições de produção. A seção de cartas de leitores "A voz e a vez do leitor" é publicada diariamente na página 07 do jornal BOM DIA Bauru, em um espaço bem destacado, contendo as cartas que os leitores enviam à redação, seja por correspondência ou e-mail, opinando sobre o jornal. As cartas devem conter o nome e endereço completos do leitor e um número de telefone para contato.

Constituímos o corpus de pesquisa a partir de um tema relacionado às práticas de informação, e que envolvesse a leitura como uma mediação entre

\footnotetext{
${ }^{5}$ Fonte: INOVAÇÃO inteligência comercial: Diario de SP e Rede Bom Dia. 2012. Slide. Disponível em: <http://www.slideshare.net/inovacaointel/diario-de-sp-e-rede-bom-dia-2012-inovao-intelignciacomercial>. Acesso em: 10 jul. 2012.
} 
produtores e leitores numa conjuntura dada. Tendo como tema a mudança do periódico em setembro de 2010, foram selecionadas 30 cartas de leitores referentes à prática de informação e leitura do jornal BOM DIA ${ }^{6}$. Observamos de início, os textos do jornal anunciando as mudanças, e em seguida, acompanhamos a seção "A voz e a vez do leitor", a fim de selecionarmos e analisarmos as cartas em que os leitores comentam sua opinião sobre o novo jornal e a consequência em suas práticas, e como a mudança foi recebida por eles no período de um mês. Realizamos um acompanhamento do jornal pela sua leitura diária nos meses de setembro a outubro de $2010^{7}$ a fim de selecionarmos o corpus para análise. Adquirimos os jornais, pois assinamos o periódico, e também realizamos consulta no arquivo do jornal, para confirmarmos o material bruto coletado ${ }^{8}$. Após a mudança, realizada no domingo dia 26 de setembro de 2010, as cartas de leitores sobre 0 novo BOM DIA foram publicadas a partir da terça-feira, dia 28 de setembro até 0 final do mês de outubro de 2010. De 30 cartas iniciais, foram excluídas 07, por se tratarem de colunas e matérias específicas que o jornal apresentou após a mudança ${ }^{9}$, concentrando, portanto, as outras 23 cartas na questão da prática de leitura e suas relações com o meio de informação, assumindo as cartas de leitores como textos mediadores em que o discurso do leitor entra na esfera da produção do periódico como um efeito de sentido da leitura do jornal e a marca de um lugar de recepção do leitor e sua apropriação da informação.

Escolhemos as cartas de leitores como espaço de observação privilegiado para o estudo da apropriação da informação, porque tem um caráter público e

\footnotetext{
${ }^{6}$ Acreditamos que esse volume publicado poderia ser ainda maior, pois a mudança do periódico aconteceu na semana anterior ao pleito eleitoral do ano de 2010, com eleições para presidente, senadores, governadores, deputados federais e estaduais, concentrando, portanto, a maior parte das cartas nessa temática.

${ }^{7}$ No entanto, lemos o jornal diariamente desde a sua fundação, e podemos ser considerados leitores do periódico em questão. $O$ interesse pelo estudo das práticas de informação e leitura nesse jornal em particular, deu-se a partir da sua leitura diária, em que notamos o registro dessas práticas nos relatos de cartas de leitores, que se iniciam muitas vezes do seguinte modo: "Li no Bom Dia...."; "Leio no Bom Dia que...'; “Fiquei eufórica ao ler no Bom Dia....', e que descrevem gestos de leitura e como o leitor se constitui quando lê.

${ }^{8}$ Realizamos duas consultas ao acervo do jornal uma em agosto e outra em dezembro de 2012, o arquivo é físico e de consulta fechada, em que é necessário pedir a um funcionário as edições necessárias para análise. Os jornais estão encadernados mês a mês e não há arquivo digital anterior a meados de 2011.

${ }^{9}$ As cartas excluídas foram duas publicadas nos dias 11 de outubro e que se referiam ao novo colunista do jornal (o apresentador de TV, José Luiz Datena), duas do dia 18, duas do dia 23 e uma do dia 28 de outubro que eram referentes a uma nova seção do jornal (chamada Bom Dia Animal, que trata de reportagens sobre bichos de estimação).
} 
mediador, pois apesar de produzidas em um espaço institucional com certas regras, são feitas para serem divulgadas, e carregam ao mesmo tempo, as marcas do leitor que escreve e as do jornal que as seleciona e publica. Para o presente artigo, selecionamos algumas cartas (textos) do corpus para discussão e análise do discurso do leitor.

As cartas foram analisadas a partir do conceito de apropriação de Thompson (2009) e Almeida Junior (2009; 2007), em que a apropriação ocorre em diferentes graus, porque é uma ação que pode ser consciente ou inconsciente, pode demandar esforço interpretativo ou não, e que significa apoderar-se de uma mensagem e incorporá-la à própria vida.

Estudar as cartas de leitores, porém, não é apenas uma busca por efeitos de sentido na leitura, mas também do significado da prática de leitura para o público leitor. Deste modo, as cartas são analisadas pela posição discursiva que o sujeito leitor pode ocupar no jornal, das imagens do leitor em certas condições de produção (ORLANDI, 2009). Portanto, a prática da leitura de jornal implica, como prática discursiva, simbólica, presente nas cartas de leitores, uma relação entre a situação do leitor, definida objetivamente, e a posição que esse ocupa, as imagens que o leitor pode e deve ocupar para ser o sujeito do discurso (PÊCHEUX, 2010b). Os leitores estão estruturados discursivamente para decodificar o jornal segundo as atitudes sugeridas por Hall (1980), os três códigos de recepção do modelo Codificação/decodificação. No entanto, não podemos tomar os três códigos de recepção de Hall (1980) como categorias absolutas, já que o leitor, na perspectiva dialética, é um ser ambivalente, em que na prática de leitura ora se apropria de modo consciente, ora inconsciente, por isso, utilizamos também em nossa análise, o referencial da $A D$ e apontamentos teóricos sobre leitura, mediação e apropriação.

\section{O LEITOR POR ELE MESMO: APROPRIAÇÃO DA INFORMAÇÃO NAS CARTAS DE LEITORES DO JORNAL BOM DIA BAURU}

Nas cartas de leitores surge a posição leitor do jornal BOM DIA Bauru, quando na recepção se faz presente a função emotiva no discurso, na qual os leitores, a partir da posição de emissores, emitem seu julgamento de valor, destacando os efeitos de sentido e as qualidades produzidas na prática de leitura, 
utilizando a primeira pessoa do singular: "Sou leitora [...] fico impressionada [...] estou me acostumando..."; "[...] tenho a dizer que [...] espero que [...] senti medo! Desejo ver..."; "Achei excelente...."; "Adorei”; "Parabenizo"; "vejo muito...”; "O que mais gosto'; "Mas não sou dos que....; "Talvez ainda me acostume [...] sinto falta"; "Confesso que [..] acho que [...] sugiro ao jornal..."; "Não gostei..."; "Sou assinante [...] leio o jornal diariamente...".

Lembrando que a apropriação da informação ocorre em diferentes graus, pode ser consciente ou inconsciente, demandar esforço ou não, e que resulta na incorporação da informação à vida do leitor, expressa diversas maneiras de ler. Por isso, nas cartas de leitores analisadas, os leitores em sua apropriação da informação, optam pela aceitação, acomodação, negociação ou rejeição frente à mudança do meio e ao conteúdo veiculado, assumindo três posições no discurso: a primeira dominante, num discurso de sustentação ao jornal, quando o leitor apoia a mudança do jornal, o que resulta na tomada de posição de leitor virtual esperado pela publicação como um cúmplice ${ }^{10}$; a segunda de negociação, quando o leitor se conforma às mudanças, mas não sem resistência, pois questiona e confronta 0 jornal, num jogo entre a imagem de um leitor virtual e o real; e a terceira de oposição, negação, quando o leitor rejeita as mudanças do jornal e se posiciona como leitor adversário.

Destacamos primeiramente as cartas que apoiam a mudança efetuada pelo jornal e se posicionam a partir da imagem de leitor esperada pela publicação, oferecendo por mecanismos discursivos, a sustentação ao novo BOM DIA. É quando o sujeito leitor, no uso de elogios, de termos já utilizados pelo jornal quando divulgou a mudança, assume a posição sujeito leitor que fala a partir do perfil que 0 jornal espera do que é ser leitor do BOM DIA, num discurso de leitura parafrástica, que assume o texto do jornal num processo em que o leitor se apropria do discurso dominante que $\mathrm{o}$ jornal tem sobre si mesmo, sobre o leitor e a prática de leitura, tomando-o para si. Muitos parabenizam o jornal e a equipe elogiando o novo layout e conteúdo, formando uma imagem do jornal consonante a que o próprio jornal tem de si mesmo:

\footnotetext{
${ }^{10}$ Não utilizamos a conceituação de Eco (1993) de "leitor modelo", porque esse não existe, já que não há um leitor ideal universal capaz de atender a todas as solicitações que um texto exige, e sim um leitor moldado e esperado pela instituição em que se inserir em sua prática de leitura (NUNES, 2003).
} 
Parabéns pela nova roupagem, disposição e clareza das notícias. Mauro Santos, e-mail. (BOM DIA, 28 set. 2010, p. 7).

[...] aos cinco anos o BOM DIA é um jornal consolidado. Bonito e bom de leitura. Leitores os que mais ganham com o resultado alcançado. Aurélio Teixeira, auditor. (BOM DIA, 04 out. 2010).

O novo BOM DIA é moderno e dinâmico. E continua com foco e conteúdo. É informativo, com opiniões pertinentes. Parabéns. Ana Maciel, universitária. (BOM DIA, 07 out. 2010, p. 7).

Sou assinante do BOM DIA e leio o jornal antes de ir para o trabalho. Parabéns a toda a equipe de profissionais responsáveis pelas inovações gráficas do jornal. Paulo Pedrini, gerente de expansão. (BOM DIA, 07 out. 2010, p. 7).

Assim, nas cartas, como discurso monólogo (PÊCHEUX, 2010b), o jornal só está presente a partir da imagem que o leitor faz dele: inovador, moderno, bonito, dinâmico, pertinente. O discurso do leitor sustenta as mudanças efetuadas pelo jornal, pois as aprova e parabeniza, além de legitimá-las, no caso da leitora que elogia o novo jornal demonstrando ler o BOM DIA antes mesmo da mudança, e também o leitor que se qualifica como "assinante". As cartas também se referem às práticas de leitura, com as maneiras de ler evidenciadas pelo leitor que afirma o seu hábito de ler antes de sair para o trabalho. Em relação ao uso, há leitores que afirmam que a leitura se tornou mais dinâmica, pois é fácil de manusear, carregar, dobrar etc.

[...] O BOM DIA é antenado com os novos tempos. Informativo, bonito, diferente, fácil de manusear. Está dando gosto de ler. Hilário Gouveia, contador. (BOM DIA, 01 out. 2010, p. 7).

O que relaciona a leitura a sua prática, como o que também se encontra na carta que segue:

[...] O novo visual ficou muito mais leve e agradável de ler. Quando menos percebemos já lemos o jornal inteiro. Parabéns! Renan Silveira, estudante. (BOM DIA, 04 out. 2010, p. 7).

Da posição de sustentação, passamos a de negociação, quando o leitor tenta falar a partir do perfil, ser o leitor virtual esperado pelo jornal, mas ao se utilizar de termos de valor adversativo em seu discurso, outro leitor surge na prática de leitura. 
De leitor cúmplice passa a leitor adversário ou vice-versa, entrando no campo da leitura polissêmica em que outros sentidos sempre são possíveis. É a leitura negociada que combina códigos adaptativos e de oposição (HALL, 1980).

Mesmo não tendo a possibilidade de uma interação imediata, ainda assim, as cartas de leitores podem ser compreendidas como resposta, já que todo "discurso é resposta" (PÊCHEUX, 2010b) ainda que não plenamente interativa. Antes mesmo da mudança, no dia 20 de setembro, um leitor escreveu ao jornal a primeira carta, em que comenta as suas expectativas:

\begin{abstract}
Em relação à matéria "BOM DIA mais fácil de ler" sobre o novo projeto gráfico que o jornal estreia no próximo domingo, tenho a dizer que mudanças sempre são bem vindas. Mas (tudo tem sempre um mas, espero que isso não signifique superficialidade, leviandade e pasteurização) só de ver o exemplo de página inteira dedicado a Lindsay Lohan, senti medo! Desejo ver conteúdo e datas especiais como aniversário de Monteiro Lobato e Clarice Lispector sejam lembradas e mereçam também página inteira. Mauro Saccenti, metalúrgico. (BOM DIA, 20 set. 2010, p. 7).
\end{abstract}

A carta foi organizada pelo editor sob a rubrica "Mudanças", e demonstra a questão intertextual das cartas de leitores que mobilizam as relações de sentido em que um texto sempre se relaciona a outros textos (ORLANDI, 2009): o leitor escreve sobre a matéria publicada no dia anterior, pois no dia 19 de setembro o jornal trouxe uma simulação de como ficaria o BOM DIA após a mudança, com fotos e infográficos da nova disposição. Sobre o novo BOM DIA, o leitor afirma que "mudanças sempre são bem vindas". Assim, inicia a carta construindo a imagem de si como um cúmplice na decisão de mudança do jornal, constituindo uma posição de leitor que tenta falar a partir da imagem do leitor virtual, do perfil esperado pela publicação, e que vive numa época de intensas mudanças sociais, que "são bem vindas".

Recorte 1: mudanças sempre são bem vindas.

MAS

Recorte 2: espero que isso não signifique superficialidade, leviandade e pasteurização. 
Ao utilizar a conjunção adversativa "mas", o leitor demonstra sua opinião, de oposição, restringe o que foi dito sobre as mudanças, e desconstrói a imagem esperada pelo jornal, produzindo outra, a de um leitor adversário, que pelo mecanismo da projeção, produz uma imagem do jornal como superficial e leviano, pausterizado, e que se ocupa de celebridades, que são, portanto, elementos de sua avaliação da leitura do jornal.

Um leitor sempre pode recusar o papel que a ele é proposto porque a prática de leitura é muito mais do que uma habilidade, e pode levar a conhecer o que o texto diz e também o que ele não diz "[...] mas o constitui significativamente" (ORLANDI, 2008, p.11).

Pela antecipação, o leitor já diz ao jornal o que quer, se adianta a ele, dando também um relato emocional ambíguo da sua leitura: "senti medo" em referência a ilustração de uma celebridade na nova página do jornal apresentada em 19 de setembro; mas que também tem "desejo": ele quer que personalidades literárias também tenham destaque na publicação.

O jornal posiciona o leitor a partir de sua identificação no espaço sócio profissional: o nome e a profissão, que indicam um leitor do sexo masculino cuja profissão é a de metalúrgico; como um lugar a partir do qual fala o sujeito, para a posição que o constitui como leitor, um leitor que teme a mudança, pois é fiel a um meio de informação porque já sabe o discurso que vai encontrar. Segue abaixo a carta de outro leitor que relaciona o suporte a sua leitura:

Confesso que fiquei meio perdido com a nova organização do BOM DIA. Acho que é questão de tempo e costume. Deu para perceber que está mais limpo e tem mais texto. Porém, tem um pecado mortal; a fonte! O leitor médio que aprecie ler sofre com as diminutas letrinhas e com isso vai embora grande parte do prazer da leitura! Sugiro ao jornal, caso insista na tal fonte, que dê lupa aos assinantes. Branco Prado, email. (BOM DIA, 28 set. 2010, p. 7).

Esse leitor ainda não aceitou - e talvez nem queira - o novo BOM DIA, e como em uma paisagem em que o leitor escolhe seu caminho, ele confessa estar "meio perdido". Quanto à manifestação material do discurso o leitor opina sobre a colocação do texto no meio, e o uso que dele podemos fazer: ao falar da nova organização do jornal, se posiciona como leitor do periódico a partir do perfil 
esperado, pois revela que é uma questão de tempo e de costume, e também projeta uma imagem simpática do jornal, como mais limpa e com mais texto. O leitor faz assim, uma primeira leitura, "literal", de apreensão do documento (PÊCHEUX, 2010c). A sua leitura, contudo, já é um julgamento, em que fala a partir de um perfil de leitor. Escolhendo a conjunção adversativa "porém", o leitor inicia sua leitura interpretativa, que já é escritura (PÊCHEUX, 2010c), articulando as duas sequências:

Recorte 1: o jornal está mais limpo e tem mais texto.

PORÉM

Recorte 2: tem um pecado mortal, a fonte.

O leitor apresenta primeiramente uma argumentação a partir do perfil, mas em seguida utiliza um argumento mais forte e definitivo contra esse primeiro argumento, o que sustenta sua posição de leitor real, de posição alheia ao leitor virtual. O leitor real critica veementemente a nova fonte utilizada pelo jornal: "pecado mortal", o ponto de vista do leitor sobre a mudança projeta o jornal como um interlocutor adversário. A fonte é personificada pelo leitor e capaz de 'matar' o prazer da leitura. Enquanto no início da carta o leitor utiliza o verbo na primeira pessoa do singular, construindo um texto pessoal: "confesso", ao evocar a imagem do leitor, constrói um leitor impessoal, mas efetivo: o "leitor médio", uma voz inquestionável, pois é aquele que "aprecia ler", mas está prejudicado em sua prática de leitura, pois "sofre" com as letras pequenas, perdendo o "prazer da leitura". A contradição se manifesta quando mesmo afirmando que o jornal está em certos aspectos melhor, o leitor afirma que não dá para ler.

Logo em seguida, o leitor se marca no que diz, ao utilizar o termo assinante, e com ironia, se antecipa ao jornal, pois afirma que caso esse mantenha sua fonte, deve providenciar lupa aos leitores. Assim, quanto à posição sujeito leitor, com o uso da gradação o leitor inicia seu argumento partindo do leitor virtual; passa pela posição do leitor médio, aquele que se apresenta junto aos demais leitores; e termina com o uso do termo assinante, aquele que efetivamente, compra e paga pelo que lê. $O$ texto demonstra as diversas apropriações e posições que o leitor 
pode ocupar no discurso: de mais a menos comprometido, de efetivo ou parte de um todo, de consumidor, se constituindo em um sujeito leitor que não é sempre o mesmo, já que o sentido de uma palavra ou expressão não existe em si mesmo (em sua relação transparente com o significante), no caso, o termo leitor, mas é determinado por posições ideológicas colocadas em jogo no processo sócio histórico em que palavras, expressões e posições são produzidas e reproduzidas (PÊCHEUX, 2009).

Finalmente, temos a leitura de oposição, negação e refutação, em que os leitores questionam o meio de informação e se posicionam abertamente contra o novo BOM DIA, utilizando expressões de valor adversativo:

Não gostei do novo BOM DIA. A minha maior crítica é em relação ao tamanho das letras, muito pequenas e de difícil leitura. $O$ padrão de impressão também caiu: tem dia que vem todo borrado. Na parte editorial, não gosto do uso recorrente de mulheres com pouca roupa na capa. É vulgar e apelativo. O BOM DIA não precisa disso. Etelvina Gomes, aposentada. (BOM DIA, 07 out. 2010, p. 7).

A leitora afirma enfaticamente: "não gostei", "não gosto", "não precisa". O tamanho das letras já foi questionado nos discurso dos leitores na posição de negociação, e nesta carta a leitura aparece relacionada à sua prática: é difícil ler o novo BOM DIA, com letras pequenas e que vem todo borrado. $O$ texto desenha uma imagem exposta ao olhar (MAINGUENEAU, 2002) e a leitora aponta seus critérios de legibilidade na leitura, pois para ela, o jornal é praticamente ilegível. As questões de gênero também estão presentes nas cartas de leitores, e num total de 23 cartas analisadas, só quatro eram de mulheres.

Acho vulgar e apelativo ter todo santo dia na capa, a foto de uma mulher quase pelada. Ermínia Serrão, aposentada. (BOM DIA, 01 out. 2010 , p. 7).

Sendo produção de sentidos, a leitura tem efeitos diferentes para diferentes leitores. No caso das leitoras a estratégia editorial do BOM DIA de colocar mulheres com "pouca roupa", "quase pelada", na capa não funciona como um valor atrativo para a leitura, sendo que a prática de leitura também é influenciada por questões de gênero. Maingueneau (2011) destacou a nudez como característica dos tabloides 
europeus, pois ser tabloide implicava a nudez, como fenômeno típico. Atualmente o jornal segue com esse tipo de material, mas geralmente nas páginas internas do jornal ou na contracapa. Outra leitora critica o que acredita ser um excesso de mudanças por parte do jornal, também rejeitando o novo BOM DIA:

\begin{abstract}
Sou leitora do BOM DIA desde que foi lançado em Bauru. E fico impressionada com a quantidade de vezes em que o jornal fez mudanças gráficas. Quando estou me acostumando com a localização de uma coluna, vocês já mudam de novo. E esse formato mais leve parece mais um encarte do que um jornal inteiro. Renata Oliveira, empresária (BOM DIA, 04 out. 2010, p. 7).
\end{abstract}

Para essa leitora, o fato do jornal estar "mais leve" é um indicativo da perda de qualidade do BOM DIA, que perde as características de jornal e se transforma em outra coisa, é um "encarte". E não é uma leitora qualquer, pois seu texto qualifica sua prática: ela lê o BOM DIA desde que o jornal foi lançado. O problema, para ela, é se acostumar com um jornal que muda a todo momento, tema que aparece no discurso de outros leitores, pois a leitura de jornal também é uma questão de hábito, em que o conhecimento detalhado do jornal cria uma imagem do mesmo para cada leitor, com qualidades e características específicas.

\title{
5 CONSIDERAÇÕES FINAIS
}

A maioria das cartas de leitores apoiou o novo Bom Dia, que, segundo os leitores, estimulou a sua prática de leitura. São leitores que, em sua maioria, falam a partir da imagem de leitor esperada pelo jornal e se apropriam da posição dominante que o mesmo tem da prática de leitura, pois se prendem mais a aspectos formais e de uso do suporte, como a diagramação e layout agradável, leitura fácil, leve, que tem mais texto, está dinâmico; do que a questões de conteúdo (editorias) da informação veiculada. Essa posição dominante não pode ser considerada sempre acrítica e reprodutora, mas também nem sempre original e inovadora, sendo uma posição definida a partir de sua prática de leitura diária que é contraditória.

Como da prática de leitura efeitos são produzidos, há os leitores resistentes ao perfil de leitor virtual, que surgem mostrando que existem outros leitores nessa história. Nas cartas, percebemos as várias posições que o sujeito pode ocupar em 
sua prática de leitura: o leitor virtual e o real, numa situação de leitura negociada, com o uso de expressões de valor adversativo. Os leitores que falam da posição de negociação são os leitores exigentes, afirmando implicitamente que a mudança só se dará se a informação for considerada na forma e no conteúdo. Há aqueles que reclamam do tamanho das letras e destacam o quanto isto torna difícil a leitura, mas também apontam questões de conteúdo da informação veiculada.

O tamanho da fonte pode ser uma barreira à comunicação da informação e excluir leitores, conforme algumas cartas alertaram, pois ao folhear o jornal o leitor pode escolher outro, cuja fonte considere maior. No Brasil, dentre as dificuldades que impedem a leitura, $10 \%$ dos leitores brasileiros afirmam ter limitações de visão (INSTITUTO PRÓ-LIVRO, 2011), o que não pode ser desconsiderado por um jornal que se quer popular.

Na posição de oposição aparecem os leitores adversários, que não querem aceitar o novo BOM DIA, e podem se afastar e abandonar sua leitura. A leitura como mediação é processo complexo em que as realidades sociais investigadas são elaboradas pelas pessoas e não podem existir sem elas, porque podem desaparecer se elas deixarem de apoiá-las (JEANNERET, 2009). Com a mudança, ainda que apontada como melhor pela maioria, se dá a contradição, pois alguns serão excluídos. Outra questão é de gênero, com críticas sobre a temática da nudez. E num total de 23 cartas analisadas, só quatro eram de mulheres, apesar de essas serem as que mais leem no país (INSTITUTO PRÓ-LIVRO, 2011).

Enfim, tanto Hall (1980) quanto Pêcheux (2009) destacam o poder no âmbito do discurso, evidenciando a relação de forças que se faz valer na comunicação. Assim, é preciso destacar a diferença que existe entre o poder sobre a interpretação do texto, que pertence ao leitor em sua prática de leitura, e é atividade de apropriação, e o poder sobre o processo de construção e apresentação do texto, que pertence ao jornal, ou seja, aos meios de informação. O próprio nome da página 07 do jornal, "Sua opinião", mostra o que ele quer dizer: "este espaço leitor é seu"; mas também o que o jornal não diz: "os demais, são nossos". A seção de cartas, intitulada "A voz e a vez do leitor" implicitamente assume que antes e depois, ou seja, nas outras páginas, a voz e a vez são do jornal.

São poderes que não podem ser equiparados, pois o texto como potencial de efeitos que coloca a apropriação em curso, está sempre envolto num horizonte de 
expectativas de uma época, em que existem previsões dentro de um contexto social, histórico, político e ideológico. Contudo, os leitores são ativos na apropriação da informação, na maneira em que aceitam, negam ou incorporam as possibilidades desse mesmo texto em criar significados, pois em toda atividade do leitor há uma parte de passividade, dialeticamente, atividade e passividade se misturam em cada ato.

Mas não concebemos o jornal como mero canal de transmissão de informação, porque os meios de informação são o lugar da luta entre forças sociais em competência, e a mediação como ação, negociação que se faz presente nas cartas de leitores, tenta garantir o reconhecimento de diversas vozes junto ao jornal, daí que aparecem nas cartas de leitores as diferentes apropriações sobre o tema da mudança do periódico, como vozes que aprovam, reproduzem ou negam o discurso, ou ainda, que estão em conflito.

Nas cartas de leitores despontaram características da prática de informação de um sujeito leitor do jornal popular, cuja relevância está: no tamanho da fonte, na organização material da informação (layout), na impressão, no conteúdo e no uso. E a sua leitura pode ser outra, já que a apropriação envolve uma finalidade, pois agir sobre um objeto não significa somente compreendê-lo, mas analisar a posição que se tinha ou se tem ao atuar sobre ele. Portanto, os leitores do BOM DIA realizaram uma leitura que é um julgamento, apontando os critérios importantes para a legibilidade em sua prática de leitura.

Nesse amplo confronto que é a mediação apareceram os diferentes sujeitos nas cartas de leitores, que se apropriaram de diferentes maneiras do novo jornal, em posição de leitor cúmplice, mas também de leitores em confronto entre a imagem de leitor virtual e real e os leitores adversários, num processo que envolveu leituras dominantes, negociadas e de oposição.

O destaque desse estudo é para as apropriações do público leitor em sua prática de informação e leitura a fim de ampliar as discussões sobre a variedade de leitores existentes, numa realidade de mudança socioeconômica que suscita contradições, mas que permite a esse leitor adquirir materiais para ler. E além disso, essa pesquisa também espera contribuir para estudos futuros sobre a mediação da informação e da comunicação entre uma organização e seus públicos. 


\section{AGRADECIMENTOS:}

Agradeço ao Prof. Dr. Oswaldo F. Almeida Junior pela orientação dessa pesquisa e a CAPES pelo seu financiamento.

\section{REFERÊNCIAS}

ALMEIDA JUNIOR. O. F. Leitura, mediação e apropriação da informação. In: SANTOS, J. P. (Org.). A leitura como prática pedagógica na formação do profissional da informação. Rio de Janeiro: Biblioteca Nacional, 2007. p. 33-45.

ALMEIDA JUNIOR, O. F. Mediação da informação e múltiplas linguagens.

Tendências da Pesquisa Brasileira em Ciência da Informação, Brasília, v. 2, n.1, p.89-103, 2009. Disponível em: $<$ http://inseer.ibict.br/ancib/index.php/tpbci/article/view/17/39>. Acesso em: 10 dez. 2009.

BORTOLIN, S. Mediação oral da literatura: a voz dos bibliotecários lendo ou narrando. 2010. 232 f. Tese (Doutorado em Ciência da Informação) - Faculdade de Filosofia e Ciências, Universidade Estadual Paulista, Marília, 2010.

CAPURRO, R. Epistemologia e Ciência da Informação. In: ENCONTRO NACIONAL DE PESQUISA EM CIÊNCIA DA INFORMAÇÃO, 5., Belo Horizonte, 2003. Anais eletrônicos... Belo Horizonte: Escola de Ciência da Informação da UFMG, 2003. (CD-ROM).

DAVALLON, J. A mediação: a comunicação em processo? Prisma.com: Revista de Ciência da Informação e Comunicação do CETAC, Portugal, n. 4, 2007. Disponível em: <http://prisma.cetac.up.pt/A_mediacao_a_comunicacao_em_processo.pdf >. Acesso em: 10 jan. 2009.

GONZALEZ DE GOMEZ, M. Novas fronteiras tecnológicas das ações de informação: questões e abordagens. Ciência da Informação, Brasília, v. 33, n. 1, p. 55-67, 2004. Disponível em: <http://revista.ibict.br/ciinf/index.php/ciinf/article/view/67/61>. Acesso em: 23 set. 2012.

GUARALDO, T. S. B. Práticas de informação e leitura: mediação e apropriação da informação nas cartas de leitores de um jornal popular do interior de São Paulo. 2013. 239 f. Tese (Doutorado em Ciência da Informação) - Faculdade de Filosofia e Ciências, Universidade Estadual Paulista, Marília, 2013.

HALL, S. Encoding/decoding. In: et. al. Culture, media, language. Londres:

Hutchinson, 1980. 
INSTITUTO PRÓ-LIVRO. Retratos da leitura no Brasil. 2011. Disponível em: $<$ http://www.cultura.gov.br/site/wp-content/uploads/2012/03/Retratos-da-leitura-noBrasil.pdf>. Acesso em: 31 mar. 2012.

JEANNERET, Y. A relação entre mediação e uso no campo de pesquisa em informação e comunicação na França. Revista Eletrônica de Comunicação, Informação \& Inovação em Saúde (RECIIS), Rio de Janeiro, v. 3, n. 3, p. 25-34, 2009. Disponível em:

<http://www.reciis.icict.fiocruz.br/index.php/reciis/article/view/276/318>. Acesso em: 15 jul. 2010.

MAINGUENEAU, D. Introdução à análise do discurso. Curso de Extensão Universitária, 16-20 de maio de 2011, Unesp Assis. Notas de aula.

MAINGUENEAU, D. Análise de textos de comunicação. 2. ed. São Paulo: Cortez, 2002.

MAY, T. Pesquisa social: questões, métodos e processos. 3. ed. Porto Alegre: Artmed, 2004.

NUNES, J. H. Aspectos da forma histórica do leitor brasileiro na atualidade. In: ORLANDI, E. (Org.) A leitura e os leitores. 2.ed. Campinas: Pontes, 2003. p. 25-46.

ORLANDI, E. Discurso e leitura. 8. ed. São Paulo: Cortez, 2008.

ORLANDI, E. Análise de discurso: princípios e procedimentos. 8. ed. Campinas: Pontes, 2009.

PÊCHEUX, M. O discurso: estrutura ou acontecimento. 5. ed. Campinas: Pontes Editores, 2008.

PÊCHEUX, M. Semântica e discurso: uma crítica à afirmação do óbvio. 4. ed. Campinas: UNICAMP, 2009.

PÊCHEUX, M. A análise de discurso: três épocas (1983). In: GADET, F.; HAK, T. Por uma análise automática do discurso: uma introdução à obra de Michel Pêcheux. 4. ed. Campinas: UNICAMP, 2010a. p. 307-315.

PÊCHEUX, M. Análise automática do discurso (AAD-69). In: GADET, F.; HAK, T. Por uma análise automática do discurso: uma introdução à obra de Michel Pêcheux. 4. ed. Campinas: UNICAMP, 2010b. p. 59-158.

PÊCHEUX, M. Ler o arquivo hoje. In: ORLANDI, E. (Org.) Gestos de leitura: da história no discurso. 3. ed. Campinas: UNICAMP, 2010c.

RUÓTOLO, A.C. Audiência e recepção: perspectivas. Comunicação e Sociedade, São Bernardo do Campo, n. 30, p. 157-170, 1998.

TABAK, B. País terá 118 milhões na classe C até 2014. G1, 07 mar. 2012. Disponível em: <http://g1.globo.com/economia/noticia/2012/03/pais-tera-118milhoes-na-classe-c-ate-2014-preve-fgv.html>. Acesso em: 10 mar. 2012. 
THOMPSON, J.B. A mídia e a modernidade: uma teoria social da mídia. 11 ed. Petrópolis: Vozes, 2009.

Title

Mediation and appropriation of information in readers' letters: practice of information and reading Bom Dia Bauru newspaper

\section{Abstract}

Introduction: The present study is intended for approaching the readers as subject in their practice of information and reading BOM DIA, a popular newspaper. In this manner, this paper proposes a study on the reader and their practice of information and everyday reading in readers' letters.

Objective: The main purpose was to know the reader subject when reading a popular newspaper in some interposition in which meaning effects are produced from the appropriation of information.

Methodology: It was selected thirty readers' letters whose theme was the change of layout and articles published in September 2010, and in order to achieve the purposes, the methodology used is Discourse Analysis.

Results: In the readers' letters, the subjects are active in what they accept, reject or reproduce the newspaper speech during the understanding process. BOM DIA Bauru readers point relevant criteria in their reading such as font size, layout, printing, use and content.

Conclusion: It is highlighted appropriations and resistance from the readers in their practice of information acquisition and reading, and we contribute to amplify the discussion about the variety of existent readers in a reality of social and economical changing, which raises contradictions but allows this reader to acquire reading material.

Key words: Practices of information. Mediation. Readers' letters. Reception.

\section{Título}

Mediación y apropiación de la información en las cartas de lectores: práctica de información y de lectura del periódico Bom Dia Bauru

\section{Resumen}

Introducción: El presente estudio se centra en el lector individual en su práctica de información y de lectura del periódico BOM DIA Bauru. En este contexto, se ha propuesto estudiar el problema del lector y su práctica de información en cuanto lectura diaria en las cartas de lectores. 
Objetivos: El objetivo principal fue conocer al lector en su práctica de lectura de un periódico popular, en una mediación en la que los efectos de sentido son producidos a partir de la apropiación de la información.

Metodología: Se seleccionaron treinta cartas de sus lectores sobre el cambio de diseño y editorial que este medio sufrió en septiembre de 2010 y para estos efectos se usó la metodología de Análisis del Discurso.

Resultados: En las cartas analizadas, los lectores son sujetos activos en cuanto que aceptan, rechazan o reproducen el discurso de la prensa en el proceso de recepción. Los lectores de BOM DIA Bauru señalaron como criterio de relevancia de la información: el tamaño de fuente, el diseño, la impresión, uso y contenido.

Conclusiones: Destacan las apropiaciones y resistencias de los lectores en su práctica informacional, contribuyendo a ampliar las discusiones sobre la variedad de lectores existentes, en una realidad de cambio socioeconómico que plantea contradicciones, pero que permite al lector adquirir materiales para leer.

Palabras clave: Prácticas de información. Mediación. Cartas de lectores. Recepción.

Recebido em: 15.07.2014

Aceito em: 05.10.2014 